\title{
The Impact of Faculty Job Satisfaction on Applying Quality Systems in Najran University: An Applied Study on College of Administrative Sciences
}

\author{
Khalid Hassan Elbashir \\ Assist. Professor of General Management, AL-Neelain University, Sudan \\ Najran University, KSA \\ Aleem Alhaj Adam \\ Assist. Professor of General Management, University of Bahri, Sudan \\ Najran University, KSA
}

Received: November 06, 2016 Accepted: December 02, 2016 Published: December 11, 2016

doi:10.5296/jpag.v6i4.10433 URL: http://dx.doi.org/10.5296/jpag.v6i4.10433

\begin{abstract}
The current study is an attempt to investigate the impact of job satisfaction on the performance of faculty in the application of quality systems at the College of Administrative Sciences in Najran University, KSA. The study adopted the descriptive analytical method and the authors developed a questionnaire included four key elements of the internal work environment (Elshaweesh, 2007): size of job burdens, financial and moral incentives, technical support, and administrative support. The study was applied to the faculty members of the four programs of College of Administrative Sciences. The authors utilized the Statistical Package for Social Sciences (S.P.S.S), where results have been shown and a number of recommendations have been made.
\end{abstract}

Keywords: Job satisfaction, Quality systems, Faculty, Najran University 


\section{Introduction}

Currently, university education has a key significance all over the world, especially for the Kingdom of Saudi Arabia, where it is the main means of catching up with the advanced countries with all their massive financial resources, allowing them to hire the best educational cadres, offer the latest specialized educational tools and achieving total development that fits up with globalization and openness of the global and Saudi market towards recruiting competition. Saudi Arabia tends to saudize the jobs of the private sector that has to commit itself to the laws of this global phenomenon. Consequently, universities have to improve the quality of their outcomes, depending mainly on faculty members; their significant and key tool. This requires raising their job satisfaction level because it is the critical factor of operating available resources and implementing quality plans and programs.

Therefore, the Kingdom of Saudi Arabia endeavored to achieve qualitative and quantitative leaps and make radical changes through a number of programs procedures, short, medium and long plans, comprising seven sections, three of which were in the university stage. The first of which was to apply quality systems. Plans of the Saudi Ministry of Education focused on two important aspects; a. increase university's internal efficiency by the quality assurance of educational inputs so the national center of measurement and evaluation was established in 2000, and b. increase university's efficiency by controlling outcomes and checking quality through quality systems of the different universities.

Hence, it required the application of quality systems and obtaining academic and institutional accreditation by higher education institutions as a guarantee of unifying efforts and controlling performance. Consequently, the National Commission for Academic Accreditation and Assessment was established in 2004 to be the institution responsible for academic accreditation and quality assurance in higher education institutions.

\section{Statement of the Problem}

College of Administrative Sciences, as well as other colleges in Najran University, suffers from the poor performance of their faculty in applying quality resulted in achieving their objectives and those of the Ministry of Education regarding improving quality of outcomes. The authors think that such poor performance can be attributed to a low job satisfaction of assigned tasks and jobs as they are the fundamental stimulus and radical factor in relation to other resources and external environment (Elqariouty, 2004). Thus, university administration has to keep pace with environmental changes and to look for the best policies and ways to achieve a successful application of quality systems. The most significant factors of internal environment are: weak incentives offered by university or college, weak leadership role of providing technical and administrative support, number of faculty does not match job burdens, concerning size, type and distribution.

\section{Objectives}

1. The current study aimed at illustrating the impact of the most significant internal job factors that negatively or positively affect the status of faculty's job satisfaction at the College of Administrative Sciences. 


\section{Macrothink}

Journal of Public Administration and Governance

ISSN 2161-7104

2016, Vol. 6, No. 4

2. Investigating the impact of job satisfaction on the performance of faculty at the College of Administrative Sciences.

3. Investigating the impact of job satisfaction on the opportunities of a successful application of quality systems at the College of Administrative Sciences.

\section{Significance of the Study}

The significance of the current study lies in the interest of Saudi Ministry of Education in improving Higher Education outcomes to meet globalization that opens the borders of countries before international competition to keep pace with the great development all over the world (Abdulaziz \& Hussien, 2005). Educational systems try to have simultaneous models of educational means and resemblance of higher education outcomes to be approachable models that enable such institutions all over the world to directly hold post-graduate studies programs or have the competitive ability in labor market. Currently, there is a general attitude all over Arab and non-Arab world to apply quality systems to higher education institutions (Zedan \& Salman, 2010), particularly in Najran University due to:

1. Lack of quality studies in the university because it is an emerging one.

2. Absence of studies on the real obstacles facing quality application

3. University education.

4. Making suggestions and recommendations to solve the problems of job performance in the university.

\section{Study Questions}

The statement of the problem can be summarized in the following main question: What is the impact of faculty job satisfaction on applying quality systems at the College of Administrative Sciences?

Four minor questions emerged:

1. To what extent do the type and size of job burdens affect job satisfaction of the faculty?

2. To what extent do salaries and financial and moral incentives affect job satisfaction of the faculty?

3. To what extent does leadership role of technical support affect job satisfaction of the faculty?

4. To what extent does administrative support affect job satisfaction of the faculty?

\section{Hypotheses}

The authors hypothesize that:

"Weak performance of faculty members regarding the application of quality systems at the College of Administrative Sciences is attributed to the low level of their job satisfaction." 


\section{Macrothink}

It is further sub-divided into four minor hypotheses:

1. There is a statistically significant relationship between type and size of job burdens and the level of job satisfaction.

2. There is a statistically significant relationship between salaries and financial and moral incentives and the level of job satisfaction.

3. There is a statistically significant relationship between the leadership role of technical support and the level of job satisfaction.

4. There is a statistically significant relationship between administrative support and job satisfaction.

\section{Methodology \& Population}

The authors adopted the descriptive approach and depended on primary resources of the different reports of quality at College of Administrative Sciences, Najran University to obtain the required data. Therefore, (30)-item questionnaire utilized, comprising four domains analyzed using the Statistical Package for Social Sciences (S.P.S.S.). In addition, a sample of (88) out of (113) faculty members, rated (77.9\%) was randomly selected to test the validity of hypotheses and measure the level of job satisfaction, interpreting the low performance of applying quality systems at the College of Administrative Sciences, Najran university. The authors distributed (100) questionnaires, of which (91) were received and (3) were excluded for inaccuracy.

\subsection{Statistical Analysis}

Statistical analysis was tested using:

1. Alpha-Cronbach correlation to test the reliability of measurement tool (as shown in table 1).

Table 1. Results of Alpha-Cronbach analysis of the questionnaire's reliability

\begin{tabular}{|l|l|l|}
\hline Domains & Number of questions & $\begin{array}{l}\text { Values of Cronbach's alpha } \\
\text { correlation }\end{array}$ \\
\hline Type and size of job burdens & 8 & $88.7 \%$ \\
\hline $\begin{array}{l}\text { Salary and financial and moral } \\
\text { incentives }\end{array}$ & 7 & $85.2 \%$ \\
\hline $\begin{array}{l}\text { Leadership role of technical } \\
\text { support }\end{array}$ & 8 & $86.4 \%$ \\
\hline Administrative support & 7 & $90.2 \%$ \\
\hline
\end{tabular}




\section{Total}

(30) questions

$95.3 \%$

Table (1) illustrates that the four domains of the questionnaire achieved a high validity rate of $(95.3 \%)$, indicating that it is a valid tool.

2. Arithmetic means, standard deviations and percentages were used to order responses.

3. (One-Sample) test was conducted to test the hypotheses.

\section{Definition of Terms}

\subsection{Faculty}

They are academic qualified members and assignee to support the program and educational services that match university's mission and objectives. Others argue that a faculty member, at many universities, is mainly interested in teaching and academic research, whether partially or fully hired. In addition, s/he is able to provide administrative performance, guidance and technical consultations according to academic specialization (Hayawy, 1987).

\subsection{Financial and moral incentives}

A set of concepts related to administrative work, such as: decision making, appreciating efforts, opinions, good relations between staff and administration and promotion (Aboelnasr, 2012). Moral incentives are salaries and bonus motivating an official to show a positive job behavior and distinct performance (Elodealy, 1993)

\subsection{Job performance measurement}

It is a measurement of an official's job achievement and ability to obtain promotion in a field (Abdulwahab, 1974). There are various methods of measuring job performance (Storeg, 1995), that take three forms: A. Management by Objectives, B. Forced Distribution and C. Events registration (marks methods), followed at the colleges of Najran university, where many features to measure the performance of an official. It is divided into marks, each of which takes significant values, where officials are categorized in a descending or ascending way according to their efficiency.

\subsection{Administrative leadership}

It is the ability of the director to affect his employees and directing them in a way to obtain their obedience, respect and loyalty, energize aspiration and create an atmosphere of cooperation to achieve the objectives of administrative organization (Darweesh, A. \& Takla, T., 1972). Leadership has three basic elements: More than one person, ability to affect and clear and agreed upon objectives. In the current study, it is used to mean: University Rector, university vice rectors, college deans, vice-deans and directors.

\subsection{Developmental project}

It is a training project conducted by Najran University as an imitation of applying the indicators of the National Commission for Academic Accreditation and Assessment (NCAAA) 
in the Kingdom of Saudi Arabia. Passing this project nominates its programs to academic accreditation by NCAAA.

\subsection{AFAQ Plan}

It is the strategic plan to evaluate the achievement of higher education in the Kingdom of Saudi Arabia, identifying its needs, types, outcomes quality, and financial methods. It is a (25)-year plan from 2005 to 2030.

\section{Theoretical Framework}

\subsection{Concept and definitions of job satisfaction}

Linguistically, satisfaction is the antonym of dissatisfaction. To be satisfied with someone means that he is satisfied and occupied himself with. Terminologically, there is no one agreed upon definition. While some authors think that it is a kind of fulfilling individual needs, others think that it is the extent of being satisfied with your job. Others also think that it is the impressions and attitudes of a person towards a job and its components. It may be the psychological status of a person when one likes many aspects of a job more than others. It is a set of positive or negative feelings by which employees express their jobs. Some authors think that it is the feelings of employees towards their jobs generated by their consciousness of what is offered by these jobs (Elshaweesh, 2007). Scholars of administration, such as Stone define it as "the status by which a person integrates with his job, or that $\mathrm{s} / \mathrm{he}$ is completely overwhelmed by or interacted with the job because of his aspiration and desire to develop, progress and achieve social goals (Sultan, 2004). Louler defines it as "obtaining what is expected by a person, so one is more satisfied". Literature of organizational behavior often expresses a feeling of comfort and happiness towards job and its environment (Ashour, 1983). Some authors think that job satisfaction and enthusiasm towards job in labour life concerned with all features and positive and negative attitudes related to job and its value as observed by officials (Elsalem, 2011). Abraham Maslow and Leman Porter agree that job satisfaction is the satisfied psychological needs. Vroom (1965) believed that it is the extent of positive outcomes provided to the employee by the job. That is, satisfaction equals equality; i.e. equality of feeling of coherence and comfort achieved by job outcomes towards efforts and tasks required to be exerted or endured. In conclusion, job satisfaction is a positive feeling that results from assessing the job or experience by a person and systems of assessing job performance that ensures benefits to the organization and employees (Donald, 1987). Understanding job satisfaction requires understanding its aspects because it is difficult to give an ultimate judgment. That is, it may be partial or incomplete, i.e. general. Satisfaction is only one aspect of the job. Preferring job satisfaction is based on the importance of the aspect.

However, some studies did not prove the relation of job satisfaction to performance and rates of job circulation (Elsharaida, 2010). Many attempts of identifying and interpreting job satisfaction affecting the performance of administrative organization's members in a number of schools of thought in administration, that was pioneered by the classical school focusing on the financial aspects and job environment as conditions of job satisfaction, as well as 
motives and goals achievement, such as: Scientific management by Taylor, Administrative process by Fayol and Bureaucratic administration by Max Weber. Then, other schools emerged as a reaction to the thoughts of the classical school, e.g. human relations, behavioral school etc. The most important of them was needs theory by Maslow that tried to interpret performance according to job satisfaction. A job satisfies progressive satisfaction of five types of needs of each employees and E.R.G theory based on the principles of Maslow's theory dividing the needs into three rather than five. Herzberg's two-factor theory interpreted job satisfaction based on two groups of factors. The first is motivation-hygiene theory (they are not motivations but if they are absent they are a source of frustration and disappointment) included: job stability, justice of organizational system, enough income, supervision and subjectivity, sound social relations and job circumstances. The second was motivations that including: attracting work, workmates' estimation, job satisfaction achievement's opportunities, taking responsibilities and achievements (Elsharaida, 2010).

\subsection{Importance of job satisfaction to the faculty}

- It helps in being adapted to university work environment as the comfortable psychological status of human resources gives a greater opportunity to control work and its surrounding environment.

- Consolidates the desire to create and innovate. When a faculty member feels that all his financial and nonfinancial needs are satisfied, his desire to perform administrative and quality burdens in a distinctive way increases.

- It improves the level of ambition and progress because the faculty member who enjoys job satisfaction has a greater desire to develop his job future.

- It provides greater opportunities of job satisfaction in the university because financial and nonfinancial benefits provided by the job helps the faculty member to face life burdens and achieve aspirations as most of the faculty of Najran university are non-Saudi who emigrated to improve their financial status.

- It increases the level of effectiveness because job satisfaction makes them concentrate more in work.

- It increases productivity because job satisfaction creates a desire to have academic achievement and perform administrative burdens and quality works.

- It decreases university's operational costs because it increases fulfilled tasks and decreases dissatisfaction and labour shirking.

- It increases the level of loyalty to university. The more a faculty member feels that his financial and nonfinancial needs are satisfied, the more loyal to university he becomes.

\subsection{Concept and management systems of quality}

It is defined in Arabic source as "improve" that means sound formation and job perfection. It is based in Lisan al-Arab on "improve" and the antonym is "low-level" (Ibn Manzur, 2014). 


\section{Macrothink}

Conventionally, it is the ability of a product, service or operation to provide the target value, namely matching the purpose. The American association of quality defines it as the total features of a product that appear and reflect its ability to satisfy clear and implied needs or it is the degree of satisfaction achieved by beneficiaries and customers by satisfying and fulfilling their needs, desires and expectations (Zedan, 2010).

\subsection{Quality assurance system in higher education institutions}

Geddis (2002) defined quality assurance system as the planned and organized review process of the institution or program to determine satisfying the accepted levels of education and internal environment. Cheng (2003) defined it as a number of planned and methodological procedures required to give enough trust to the educational outcome or process at the university and fulfills quality requirements. According to Hussien (2005), it is designing or implementing a system of policies and procedures that a university performs to satisfy quality requirements, not on the stages of the educational process, but a wider one that comprises quality control of all university jobs. Elbahwash (2007) believed that it is a system of planned policies, measurements and actions by which higher education quality is achieved and developed to the extent that beneficiaries' needs and requirements are satisfied.

Accordingly, the authors conclude that it represents a system of minor administrative systems and operations, styles and procedures implemented by the university to assure quality and prevent the mistakes of inputs, processes and outcomes of private and public higher education institutions (Zedan, 2010). Hence, it is able to fulfill and stick to international standards of quality that their application helps the university obtain academic accreditation by local, regional or international institutions.

\subsection{Principles of quality systems at the College of Administrative Sciences}

College of Administrative Sciences designed an internal system of quality management and assurance because it is an administrative process that aims to achieve the best performance in all authorities, sections and departments according to available facilities. It is mainly based on continuous improvement. In addition, it includes a collection of policies, rules and procedures, aiming to achieve the college's mission and aims according to defined and published rules and conditions. The four programs sought to apply the educational standards and features according to the mission and aims of the university to improve the educational product by selecting good inputs and applying various processes of fulfilling students' needs and improving their different skills that fulfill market requirements and society needs. Therefore, quality management systems of the college's programs participated in the inputs, processes and outcomes (as shown in table 2): 


\section{MInstitute ${ }_{\text {Mnk }}^{\text {Macrothink }}$}

Journal of Public Administration and Governance

ISSN 2161-7104

2016, Vol. 6, No. 4

Table 2. Shared factors of quality systems at the College of Administrative Sciences

\begin{tabular}{|c|c|}
\hline $\begin{array}{l}\text { Components of } \\
\text { quality system }\end{array}$ & $\begin{array}{l}\text { Requirements of quality systems at the College of Administrative Sciences, } \\
\text { Najran university }\end{array}$ \\
\hline Students (inputs) & $\begin{array}{l}\text { Adopting effective and fair policies of admission and registration that match the } \\
\text { requirements identified. }\end{array}$ \\
\hline $\begin{array}{l}\text { the faculty } \\
\text { (inputs) }\end{array}$ & $\begin{array}{l}\text { Selecting defined standards of hiring that match the requirements of the program, } \\
\text { where the number of the faculty matches that of students. }\end{array}$ \\
\hline $\begin{array}{l}\text { Study plan } \\
\text { (inputs) }\end{array}$ & $\begin{array}{l}\text { An updated study plan to be reviewed by specialists according to the } \\
\text { requirements of job market and society needs and are approved by the decree of } \\
\text { college and university. }\end{array}$ \\
\hline \multirow{5}{*}{$\begin{array}{l}\text { Curricula } \\
\text { (inputs) }\end{array}$} & $\begin{array}{l}\text { An authorized description of the program that comprises clear and measurable } \\
\text { learning objectives and outcomes created according to standardized comparisons } \\
\text { to other simultaneous programs of pioneering universities regionally and } \\
\text { internationally. }\end{array}$ \\
\hline & Having a matrix of achieving learning outcomes by curricula. \\
\hline & Matrices indicating the achievement of learning objectives and outcomes. \\
\hline & Matrices indicating the achievement of learning outcomes by curriculum content. \\
\hline & Tables of each curriculum specifications to assure achieving learning outcomes. \\
\hline \multirow[b]{2}{*}{$\begin{array}{l}\text { Services and } \\
\text { facilities } \\
\text { (inputs) }\end{array}$} & Offering equipped lecture rooms that match the number of students. \\
\hline & Providing faculty members, students and administrators with computer devices \\
\hline \multirow[t]{4}{*}{$\begin{array}{l}\text { Students } \\
\text { (processes) }\end{array}$} & $\begin{array}{l}\text { Holding programs of introducing, preparing and qualifying new students' } \\
\text { programs. }\end{array}$ \\
\hline & Having interest in summer and other activities that consider students' skills. \\
\hline & $\begin{array}{l}\text { Applying an authorized system of academic accreditation, monitoring poor and } \\
\text { distinguished students, creating programs of developing and consolidating their } \\
\text { performance in the program and applying a system of complaints and } \\
\text { suggestions. }\end{array}$ \\
\hline & $\begin{array}{l}\text { Providing guides and documents that secure students' rights and responsibilities. } \\
\text { Additionally, their concept and application are just and transparent and they are }\end{array}$ \\
\hline
\end{tabular}




\begin{tabular}{|c|c|}
\hline & available to all students. \\
\hline & Holding meetings of vocational guidance regarding jobs related to specialization. \\
\hline \multirow{9}{*}{$\begin{array}{l}\text { Curricula } \\
\text { (processes) }\end{array}$} & $\begin{array}{l}\text { Courses' periodical reports that include information on strategies' effectiveness, } \\
\text { learning outcomes achievement and using their results in preparing the program's } \\
\text { report. }\end{array}$ \\
\hline & $\begin{array}{l}\text { Preparing a file of each course that includes its full data (description, report, } \\
\text { books approved as resources, examples of teaching activities, exam's samples and } \\
\text { follow-up tables of each student). }\end{array}$ \\
\hline & Providing an annual list of approved books in each course. \\
\hline & $\begin{array}{l}\text { A consultative board of the program, where practitioners of related professions } \\
\text { and jobs participate to monitor and give consultation on the content and quality } \\
\text { of the program. }\end{array}$ \\
\hline & Approving the unified test style of each course taught by many faculty members. \\
\hline & $\begin{array}{l}\text { Continuously updating curricula to keep pace with modern scientific } \\
\text { developments and annually allowing this at the rate of } 1-5 \% \text { and reviewing and } \\
\text { approving them by the board of the department. }\end{array}$ \\
\hline & $\begin{array}{l}\text { Curriculum's book is the inferior limit of the subject to be accompanied by } \\
\text { studies defined by those in charge of each curriculum. }\end{array}$ \\
\hline & Applying various teaching strategies that match the nature of curricula. \\
\hline & $\begin{array}{l}\text { Applying various evaluation styles, such as: } \\
\text {-Tests to evaluate learning outcomes-direct and indirect observation to evaluate } \\
\text { learning outcomes related to skills of dealing with others, communication skills } \\
\text { and information and kinetic self techniques- surveying students' opinions of } \\
\text { assessing satisfaction (curriculum, teaching and assessment methods and the } \\
\text { faculty)- reports of curricula and the program- external reviewer reports- } \\
\text { assessing exam's paper to test measuring content by exam's questions according } \\
\text { to its relative importance and its ability to measure learning outcomes. }\end{array}$ \\
\hline \multirow{4}{*}{$\begin{array}{l}\text { Library and learning } \\
\text { resources(processes) }\end{array}$} & Providing a library with a content that fulfills the needs of beneficiaries. \\
\hline & Offering internetworking services to the faculty. \\
\hline & Offering internetworking services to students. \\
\hline & $\begin{array}{l}\text { Balanced representation of men and women in granting the membership of the } \\
\text { different committees. }\end{array}$ \\
\hline
\end{tabular}




\begin{tabular}{|c|c|}
\hline \multirow{6}{*}{$\begin{array}{l}\text { Faculty members } \\
\text { (processes) }\end{array}$} & Improving the faculty in using teaching and learning techniques. \\
\hline & $\begin{array}{l}\text { Qualifying academic and administrative leadership in an atmosphere of job } \\
\text { stability that decreases the rates of quitting the program. }\end{array}$ \\
\hline & $\begin{array}{l}\text { Conducting a periodic assessment of the faculty's performance that includes: peer } \\
\text { student assessment- self assessment- academic achievement assessment. }\end{array}$ \\
\hline & Encouraging and rewarding initiatives of the faculty and officials in the program. \\
\hline & $\begin{array}{l}\text { Providing and facilitating the circulation of a clear document of the tasks and } \\
\text { responsibilities of the faculty. }\end{array}$ \\
\hline & Applying clear, just and cohesive policies and procedures to the faculty. \\
\hline $\begin{array}{l}\text { Operational rules } \\
\text { and regulations } \\
\text { (processes) }\end{array}$ & $\begin{array}{l}\text { Issuing a decree of formally delegating responsibilities in signing documents of } \\
\text { the authorizer that clearly defines the delegated responsibilities and those of } \\
\text { submitting reports of the decisions made. }\end{array}$ \\
\hline \multirow{5}{*}{$\begin{array}{l}\text { Facilities and } \\
\text { support } \\
\text { (processes) }\end{array}$} & $\begin{array}{l}\text { Providing annual suggestions of the budget where it is monitored and edited after } \\
\text { approving the proposed budget and dedicating the required financial resources. }\end{array}$ \\
\hline & $\begin{array}{l}\text { Giving authorities of clearly defined expenditure to achieve an effective } \\
\text { administration. }\end{array}$ \\
\hline & $\begin{array}{l}\text { Providing full lists of the program's equipment, including those kept by the } \\
\text { faculty for teaching and scientific research purposes. }\end{array}$ \\
\hline & $\begin{array}{l}\text { Periodic monitoring of equipment assessment and performing the required } \\
\text { replacement or maintenance. }\end{array}$ \\
\hline & Procedures of organizing shared use of facilities and equipment. \\
\hline \multirow{5}{*}{$\begin{array}{l}\text { Graduates } \\
\text { (outcomes) }\end{array}$} & Registering student's success and level of achievement in the program. \\
\hline & $\begin{array}{l}\text { Monitoring the results of assessing students' performance, comparing them to } \\
\text { clear standards, writing reports and creating plans of continuous improvement } \\
\text { according to the report's results. }\end{array}$ \\
\hline & $\begin{array}{l}\text { Results of measuring the achievement of learning outcomes of the curricula and } \\
\text { the program. }\end{array}$ \\
\hline & $\begin{array}{l}\text { Creating regular reports of the key performance indicators to be submitted to the } \\
\text { senior leadership that defines the current situation of performance indicators. }\end{array}$ \\
\hline & $\begin{array}{l}\text { Surveying the eighth level students' opinions on the program and the experience } \\
\text { of the student. }\end{array}$ \\
\hline
\end{tabular}




\begin{tabular}{|l|l|}
\hline & $\begin{array}{l}\text { Surveying the graduates' opinions on vocational efficiencies required by the } \\
\text { program and their relation to jobs. }\end{array}$ \\
\cline { 2 - 3 } & $\begin{array}{l}\text { Surveying the hiring bodies' opinions to determine the graduates' strengths and } \\
\text { weaknesses. }\end{array}$ \\
\cline { 2 - 2 } & $\begin{array}{l}\text { Implementing training programs of the graduates, aiming to improve their } \\
\text { abilities and vocational skills. }\end{array}$ \\
\hline
\end{tabular}

Source: The authors, 2016

\section{Field Study}

\subsection{Faculty performance in quality assurance at the College of Administrative Sciences}

According to the statistics of the academic year 2015/2016, the performance of the faculty in implementing quality assurance was generally weak, although the university exceeded the target indicator of training the faculty. While the target of Aafaq plan was (35\%), the university achieved (53\%). The university scored two weak rates in the satisfaction of the faculty of administrative systems, rating (3.1). The same rate was scored in the efficiency of infrastructure. It was noted that these figures were unclearly mentioned in the reports of university performance indicators, unlike the good attempts where the university achieved good rates (Reports of Najran University's performance indicators, 2015).

Reports of Saudi Ministry of Education and Najran University reported a decrease of target indicators of the higher education future plan "Aafaq" that defined (14) programs to be applied in the second round. Najran university's programs that evaluate students learning outcomes rated (29\%) out of (70\%) and that the College of Administrative sciences rated less than $(10 \%)$. Programs applying for academic accreditation conditioned on applying standards of NCAAA rated $(14 \%)$ out of $(85 \%)$. The university also failed to keep what it achieved during the academic year (35-36) as it rated (100\%) of keeping its faculty as non-Saudi faculty who resigned were (85) members at the university, of whom (11) were at the College of Administrative Sciences. It was a high rate if deduced from non-Saudi experienced and related to quality works faculty members.

Reports of reviewing the performance of the College of Administrative Sciences' faculty illustrated that the program's section, known as quality support plans achieved weak performance on the fourteen quality standards, where performance dis not exceed $(52 \%)$ in 2014/2015 and 2015/2016. The report of internal reviewers at the College of Administrative Sciences issued on 5/04/206, illustrated that the four programs did not have any achievement of the current stage's requirements according to quality plan, except for reviewing and updating public administration program's mission. No recommendation of the external reviewers, created according to the development project, was implemented regarding the fourteen programs nominated for academic accreditation from NCAAA. The result was weak and there was a great decrease of the percentage of translating quality documents of all programs. However, work circulation increased among the faculty and rated $(9.7 \%)$ in the 


\section{Al Macrothink \\ Journal of Public Administration and Governance \\ ISSN 2161-7104 \\ 2016, Vol. 6, No. 4}

academic year 2015/2016, supporting the hypothesis of "weakness of job satisfaction".

10.2 Personality Analysis

Table 3. Data of sampling

\begin{tabular}{|l|l|l|l|}
\hline Variable & Type & Number & Percentage \\
\hline \multirow{4}{*}{ Gender } & Male & 51 & 58 \\
\cline { 2 - 4 } & Female & 37 & 52 \\
\hline \multirow{4}{*}{$\begin{array}{l}\text { Academic } \\
\text { Qualification }\end{array}$} & Lecturer & 26 & 29.5 \\
\cline { 2 - 4 } & Assistant Professor & 48 & 54.5 \\
\cline { 2 - 4 } & Associate professor & 8 & 9.9 \\
\cline { 2 - 4 } & Professor & 6 & 6.8 \\
\hline \multirow{5}{*}{ Academic department } & Public administration & 26 & 29.5 \\
\cline { 2 - 4 } & Business administration & 35 & 39.8 \\
\cline { 2 - 4 } & Law & 20 & 22.7 \\
\cline { 2 - 4 } & Accounting & 7 & 8 \\
\hline
\end{tabular}

Source: Questionnaire of the field study, October 2016

Results of questionnaire's analysis (in table 3) illustrated that the majority of participants were males rated (58\%). Assistant professors were the largest percentage, rated $(54.5 \%)$. Concerning academic departments, the largest part was obtained by business administration rated $(39.8 \%)$. However, accounting department was the least rated (8\%). 
10.3 Response analysis and hypotheses reliability

Table 4. Percentages of the participants' responses to the size and type of works assigned

\begin{tabular}{|c|c|c|c|c|c|c|c|c|}
\hline $\begin{array}{l}\text { Job } \\
\text { burdens } \\
\text { enable me } \\
\text { to } \\
\text { effectively } \\
\text { participate } \\
\text { in quality } \\
\text { works. }\end{array}$ & $\begin{array}{l}\text { I am satisfied } \\
\text { with } \\
\text { eparticipation in } \\
\text { college's } \\
\text { decision } \\
\text { making and } \\
\text { administrative } \\
\text { participation. }\end{array}$ & $\begin{array}{l}\text { Size of } \\
\text { work } \\
\text { allows } \\
\text { me show } \\
\text { my skills } \\
\text { and } \\
\text { abilities. }\end{array}$ & $\begin{array}{l}\text { The size } \\
\text { quality } \\
\text { administrati } \\
\text { burdens } \\
\text { appropriate. }\end{array}$ & $\begin{array}{l}\text { ofLeadership } \\
\text { andobserves } \\
\text { ve my personal } \\
\text { isinterests on } \\
\text { making } \\
\text { decisions. }\end{array}$ & $\begin{array}{l}\text { Notified } \\
\text { assignments } \\
\text { al are } \\
\text { nappropriate } \\
\text { to my job. }\end{array}$ & $\begin{array}{l}\text { I usually } \\
\text { receive } \\
\text { update on my } \\
\text { job attitudes } \\
\text { from (my } \\
\text { commanding } \\
\text { officer). }\end{array}$ & $\begin{array}{l}\text { My job } \\
\text { duties } \\
\text { are clear } \\
\text { and } \\
\text { defined. }\end{array}$ & \\
\hline 88 & 88 & 88 & 88 & 88 & 88 & 88 & 88 & Valid \\
\hline 0 & 0 & 0 & 0 & 0 & 0 & 0 & 0 & Missing \\
\hline 2.99 & 3.08 & 2.86 & 3.32 & 2.88 & 2.61 & 2.24 & 2.13 & Mean \\
\hline 3.00 & 3.00 & 3.00 & 3.00 & 3.00 & 3.00 & 2.00 & 2.00 & Median \\
\hline 3 & 2 & 3 & 4 & 3 & 3 & 2 & 1 & Mode \\
\hline 1.099 & 1.186 & 1.186 & 1.189 & 1.102 & 1.055 & 1.039 & 1.059 & $\begin{array}{l}\text { Std. } \\
\text { Deviation }\end{array}$ \\
\hline
\end{tabular}

Source: Questionnaire of the field study, October 2016

Table 5. (One-Sample) test of the type and size of works assigned

\begin{tabular}{|l|l|l|l|l|}
\hline \multirow{2}{*}{$\begin{array}{l}\text { Hypothesis } \\
\text { relationship between the type }\end{array}$} & \multicolumn{2}{|l|}{$\begin{array}{l}\text { General } \\
\text { attitude }\end{array}$} \\
\cline { 2 - 6 } and size of works and job satisfaction level & $\begin{array}{l}\text { Mean } \\
\text { Differenc }\end{array}$ & $\begin{array}{l}\text { Sig. } \\
\text { (2-tailed) }\end{array}$ & T & \\
\hline My job duties are clear and defined. & 2.125 & .000 & 18.818 & Agree \\
\hline $\begin{array}{l}\text { I usually receive update on my job attitudes from } \\
\text { one channel (my commanding officer). }\end{array}$ & 2.239 & .000 & 20.204 & Agree \\
\hline Notified assignments are appropriate to my job. & 2.614 & .000 & 23.236 & Neutral \\
\hline
\end{tabular}




\begin{tabular}{|c|c|c|c|}
\hline $\begin{array}{l}\text { Leadership observes my personal interests on } 2.875 \\
\text { making decisions. }\end{array}$ & .000 & 24.477 & Neutral \\
\hline $\begin{array}{l}\text { The size of quality and administrative burdens is } 3.318 \\
\text { appropriate. }\end{array}$ & .000 & 26.169 & Disagree \\
\hline $\begin{array}{l}\text { Size of work allows me show my skills and } 2.864 \\
\text { abilities. }\end{array}$ & .000 & 22.651 & Neutral \\
\hline $\begin{array}{l}\text { I am satisfied with participation in college's } \\
\text { decision making and administrative participation. }\end{array}$ & .000 & 24.351 & Disagree \\
\hline $\begin{array}{l}\text { Job burdens enable me to effectively participate in } 2.989 \\
\text { quality works. }\end{array}$ & .000 & 25.521 & Neutral \\
\hline
\end{tabular}

Source: Questionnaire of the field study, October 2016

Tables ( $4 \& 5$ ) showed that the general attitude of responses was neutrality and dissatisfaction concerning the majority of questions of "internal job factors related to type and size of job burdens" and that the degree of job satisfaction did not match the type and size of quality works. Agreement was only limited to the clarity of job tasks and unity of contact channels within college's organizational structure. It was obtained by the responses of public administration's participants. If this department faculty's responses were excluded, the majority of responses would be "disagree" and neutral.

To test the hypothesis that "there is a statistically significant relationship between size and type of job burdens and the level of job satisfaction", (One-Sample) test was used at a significance level of $(0.05 \%)$. Hence, it is accepted if the significance value was less than $(0.05 \%)$ and it is refused if it is greater. According to significance value illustrated in table (5) rated (0.00), the hypothesis is valid. 
Table 6. Percentages of the participants' responses to salaries and financial and moral incentives

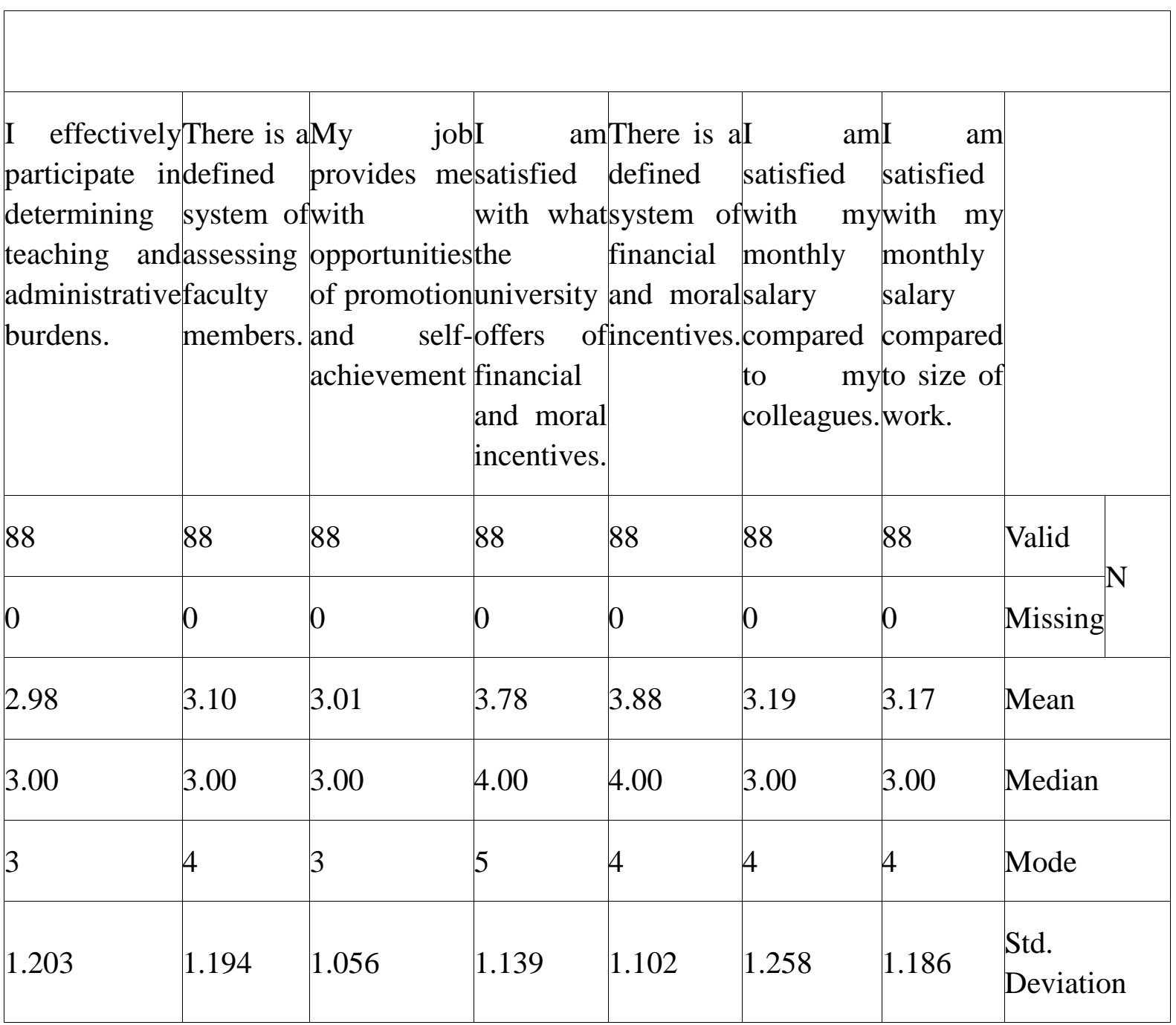

Source: Questionnaire of the field study, October 2016

Table 7. (One-sample) test of salaries and financial and moral incentives

\begin{tabular}{|c|c|c|c|c|}
\hline Hypothesis: There is a statistical significant & Test V & lue $=0$ & & General \\
\hline $\begin{array}{l}\text { satisfaction } \\
\text { and the level of job satisfaction. }\end{array}$ & M. Di & $\begin{array}{l}\text { Sig. } \\
(2-\text { tailed })\end{array}$ & & \\
\hline $\begin{array}{l}\text { I am satisfied with my monthly salary compared to } \\
\text { size of work. }\end{array}$ & 3.170 & .000 & 25.070 & Disagree \\
\hline $\begin{array}{l}\text { I am satisfied with my monthly salary compared to my } \\
\text { colleagues. }\end{array}$ & 3.193 & .000 & 23.809 & Disagree \\
\hline
\end{tabular}




\begin{tabular}{|l|l|l|l|l|}
\hline $\begin{array}{l}\text { There is a clear system of financial and moral } \\
\text { incentives. }\end{array}$ & 3.875 & .000 & 32.991 & Disagree \\
\hline $\begin{array}{l}\text { I am satisfied with what the university offers of } \\
\text { financial and moral incentives. }\end{array}$ & 3.784 .000 & 31.162 & Disagree \\
\hline $\begin{array}{l}\text { My job provides with opportunities of promotion and } \\
\text { self- actualization. }\end{array}$ & 3.011 & .000 & 26.755 & Disagree \\
\hline $\begin{array}{l}\text { There is a clear system of assessing faculty members. } \\
\text { I effectively participate in determining teaching and }\end{array}$ & 2.102 & .000 & 24.369 & Disagree \\
\hline administrative burdens. & .000 & 23.212 & Neutral \\
\hline
\end{tabular}

Source: Questionnaire of the field study, October 2016

Tables ( $6 \& 7$ ) pointed out that participants generally disagree on salaries and financial and moral incentives, except the neutrality of their participating in determining teaching burdens. If the responses of public administration department's responses are excluded, the answer is "disagreement". In addition, "strongly agree" responses rated (9.1\%) and "agree" rated (25\%) regarding the salary compared to size of work and the salaries of work mates. By excluding Saudi faculty, enjoying good financial status and high compensations compared to non-Saudi ones, the largest section becomes "disagree" because they believe that what they get is unfair compared to their workmates.

To test the hypothesis that "there is a statistically significant relationship between salaries and financial and moral incentives and the level of job satisfaction", (One-Sample) test was used at a significance level of $(0.05 \%)$. Hence, it is accepted if the significance value was less than $(0.05 \%)$ and it is refused if it is greater. According to significance value illustrated in table (7) rated $(0.00)$, the hypothesis is valid. 
Table 8. Percentage of participants' responses to leadership's role in technical support

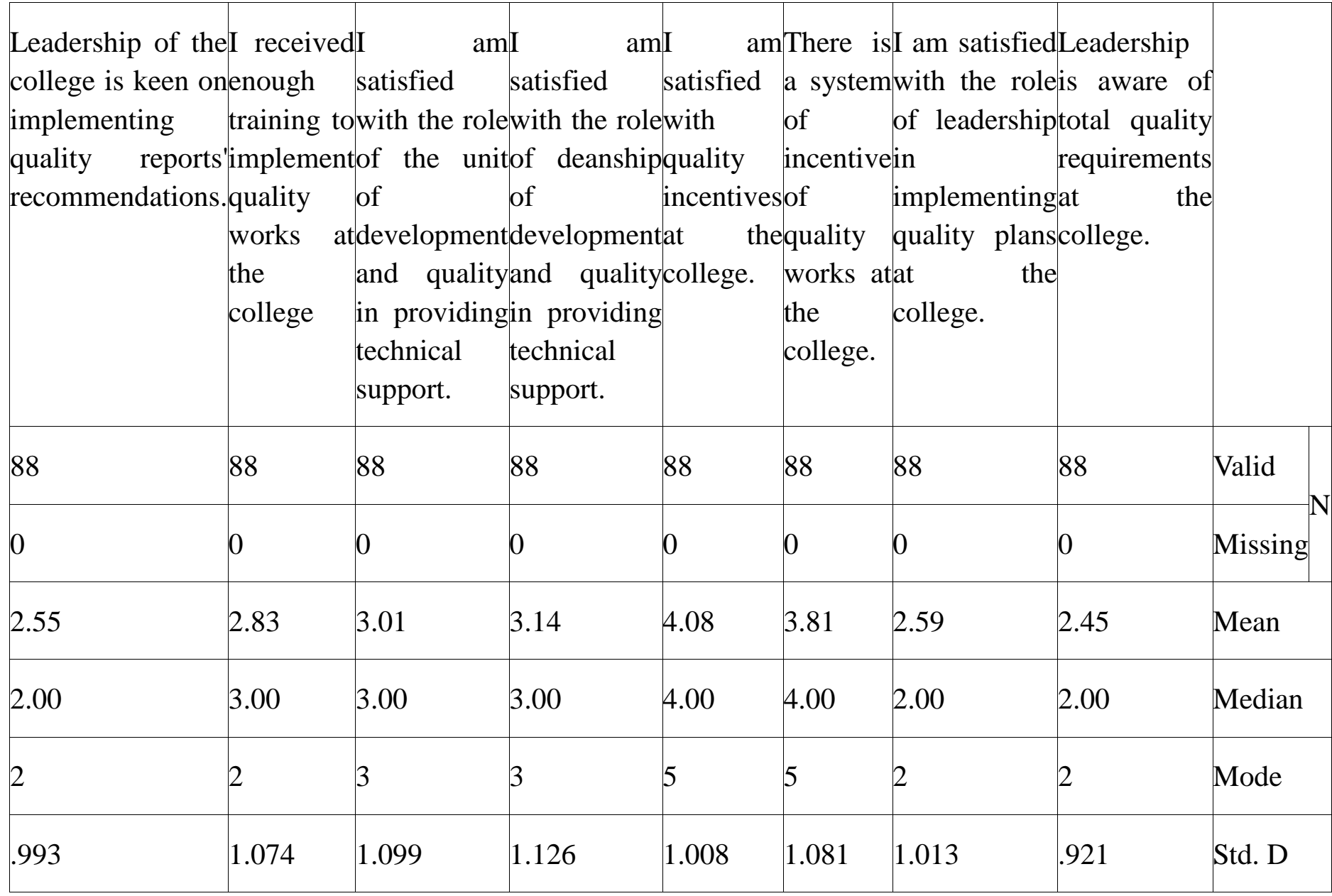

Source: Questionnaire of the field study, October 2016

Table 9. (One-Sample)Test of leadership's role in technical support

Hypothesis: There is a statistical significant relationshipTest Value $=0$ between the role

of leadership in technical support and job satisfaction level

Leadership is aware of total quality requirements at the college.

I am satisfied with the role of leadership in implementing quality plans at the college. 2.455 Difference (2-tailed)

There is a system of incentive of quality works at the college. 


\begin{tabular}{|l|l|l|l|l|}
\hline I am satisfied with quality incentives at the college. & 4.080 & .000 & 37.956 & Disagree \\
\hline $\begin{array}{l}\text { I am satisfied with the role of deanship of development and } \\
\text { quality in providing technical support. }\end{array}$ & 3.136 & .000 & 26.122 & Disagree \\
\hline $\begin{array}{l}\text { I am satisfied with the role of the unit of development and } \\
\text { quality in providing technical support. }\end{array}$ & 3.011 & .000 & 25.715 & Disagree \\
\hline $\begin{array}{l}\text { I received enough training to implement quality works at } \\
\text { the college. }\end{array}$ & 2.830 & .000 & 24.703 & Neutral \\
\hline $\begin{array}{l}\text { Leadership of the college is keen on implementing quality } \\
\text { reports' recommendations. }\end{array}$ & 2.545 & .000 & 24.042 & Neutral \\
\hline
\end{tabular}

Source: Questionnaire of the field study, October 2016

Tables $(8 \& 9)$ showed that participants generally agreed that the college's leadership was aware of quality requirements and satisfied of its role in implementing quality plan. Most of other responses were dissatisfied. Faculty also differed on receiving enough training to implement quality works and leadership's adherence to implement the recommendations of quality reports. Accordingly, the general attitude towards "the role of leadership in technical support and the level of job satisfaction" was disagreement. The degree of job satisfaction of this section did not match size and type of quality works at the college.

To test the hypothesis that "there is a statistically significant relationship between the role of leadership in providing technical support and the level of faculty members' job satisfaction", (One-Sample) test at a significance level of $(0.05 \%)$ was used. Consequently, this hypothesis is approved if the significance level is less than $(0.05 \%)$ and if it was more, it is refused. According to significance value illustrated in table (9) rated (0.00), the hypothesis is valid. 


\section{Macrothink}

Table 10. Percentage of participants' responses to administrative support

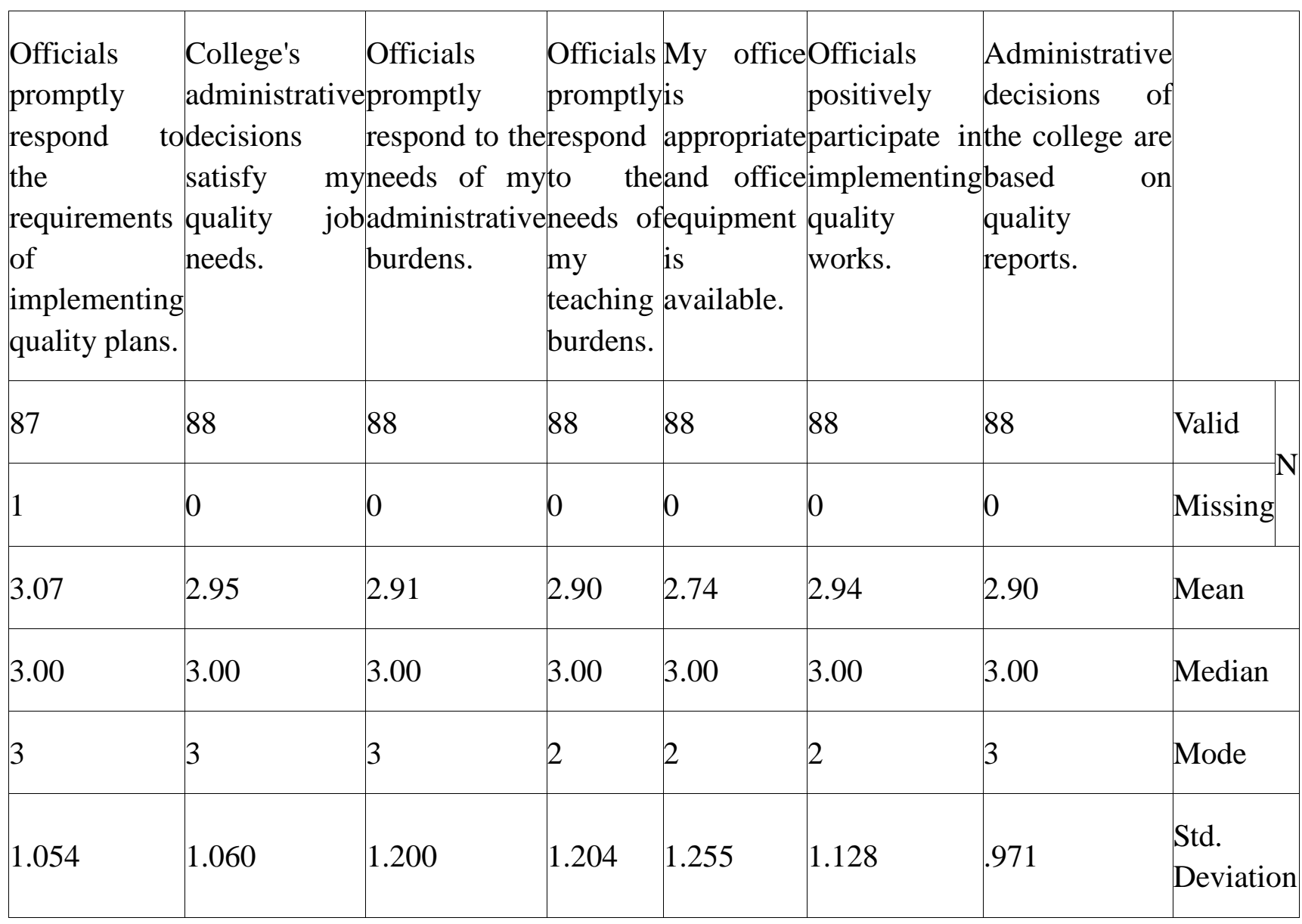

Source: Questionnaire of the field study, October 2016

Table 11. (One-Sample) Test of administrative support

\begin{tabular}{|c|c|c|c|c|}
\hline \multicolumn{4}{|c|}{ Hypothesis There is a statistically significantTest Value $=0$} & \multirow{2}{*}{$\begin{array}{l}\text { General } \\
\text { attitude }\end{array}$} \\
\hline $\begin{array}{l}\text { relationship between administrative support and } \\
\text { job satisfaction. }\end{array}$ & Mean & $\begin{array}{l}\text { Sig. } \\
(2 \text {-tailed })\end{array}$ & $\mathrm{T}$ & \\
\hline $\begin{array}{l}\text { Administrative decisions of the college are based } \\
\text { on quality reports. }\end{array}$ & 2.898 & .000 & 27.986 & Neutral \\
\hline $\begin{array}{l}\text { Officials positively participate in implementing } \\
\text { quality works. }\end{array}$ & 2.943 & .000 & 24.474 & Neutral \\
\hline $\begin{array}{l}\text { My office is appropriate and office equipment is } \\
\text { available. }\end{array}$ & 2.739 & .000 & 20.474 & Neutral \\
\hline
\end{tabular}




\begin{tabular}{|l|l|l|l|l|}
\hline $\begin{array}{l}\text { Officials promptly respond to the needs of my } \\
\text { teaching burdens. }\end{array}$ & .000 & 22.581 & Neutral \\
\hline $\begin{array}{l}\text { Officials quickly respond to the needs of my } \\
\text { administrative burdens. }\end{array}$ & 2.909 & .000 & 22.742 & Neutral \\
\hline $\begin{array}{l}\text { College's administrative decisions satisfy my } \\
\text { quality job needs. }\end{array}$ & .000 & 26.139 & Neutral \\
\hline $\begin{array}{l}\text { Officials promptly respond to the requirements of } \\
\text { implementing quality plans. }\end{array}$ & 3.069 & .000 & 27.152 & Disagree \\
\hline
\end{tabular}

Source: Questionnaire of the field study, October 2016

Tables (10 \& 11) illustrate that the general attitude of responses was neutrality and dissatisfaction concerning the majority of questions of "internal job factors related to type and size of job burdens" and that the degree of job satisfaction did not match the type and size of quality works. In addition, agreement was only limited the clarity of job tasks and unity of contact channels within college's organizational structure.

To test the hypothesis that "there is a statistically significant relationship between administrative support and job satisfaction", (One-Sample) test at a significance level of $(0.05 \%)$ was used. Consequently, this hypothesis is approved if the significance level is less than $(0.05 \%)$ and if it was more, it is refused. According to significance value illustrated in table (11) rated (0.00), the hypothesis is valid.

Regarding the reliability of the four minor hypotheses, the main hypothesis "weak performance of faculty members regarding the application of quality systems at the College of Administrative Sciences is attributed to the low level of their job satisfaction" is valid by excluding other external factors.

\section{Results}

1. There is unbalance between college's objectives and those of the faculty.

2. Type and size of job burdens do not match the nature of the faculty's work and contradict with the nature and standards of quality. Accordingly, there is an inability of performing quality works in due time and supposed quality.

3. There is a non-application of a defined and clear system of periodically assessing the faculty and financially and morally motivating them for quality that is extra load added to their teaching duties.

4. There are major differences among the faculty regarding salaries and financial and moral incentives. In addition, absence of having a scientific basis of these differences creates 
dissatisfaction among most of them.

5. There is a poor influence of the departments of development, quality and technical support at the university and college in providing appropriate and adequate training courses to empower the faculty to implement quality activities according to NCAAA's standards. In addition, leadership administrative decisions are weak in handling such drawbacks.

6. There is a weak participation from the faculty in the administration style and quality plans.

7. There are no clear and defined authorities and responsibilities of development and quality bodies in the university and colleges. Furthermore, there is no clear and written relationship between quality coordinators of academic programs and development and quality units or between quality and development units at colleges and quality and development units at the university.

8. Administrative decisions at the College of Administrative Sciences are made without observing faculty's needs and the various recommendations of quality reports. Additionally, their needs do not receive an appropriate and prompt response, decreasing the effectiveness of implementing quality standards.

\section{Recommendations}

The following recommendations have been made:

1. Holding periodic meetings of the faculty at the College of Administrative Sciences to discuss and illustrate university aims and how to achieve them.

2. Reviewing the type and size of job burdens of the faculty according to job description by university officials, including those of the College of Administrative Sciences.

3. Holding workshops at the College of Administrative Sciences to identify the efforts needed to implement academic, administrative, quality and academic advising burdens of each program or department.

4. Applying a defined and clear system to periodically assess the faculty and motivating them financially and morally for quality duties.

5. Fair distribution of salaries and financial and moral incentives among the faculty according to defined basis, e.g. size of responsibility and the burdens of administration, quality and academic advising.

6. Reviewing the nature of development, quality and technical support in the university and college by providing training courses and defining their tasks and relations within college.

7. Faculty involvement in creating a database of training needs and courses of development and quality according to which nomination's priority for the training courses on the level of members and academic programs is determined.

8. Giving a larger space for the faculty member to participate in the style of administration and defining the best methods of implementing quality plans. 
9. Making administrative decisions according to the college's quality reports and training and recruiting administrators in the team of implementing quality plans with the faculty.

\section{References}

Ibn Manzur, A. (1992). Lisan al-Arab dictionary (3rd ed). Beirut: Dar Sader

Elbahwash, E. (2007). Accreditation and quality assurance of higher education (1st Ed.). Cairo: El-nahda El-haditha Bookshop.

Elsalem, M. (2001). Human resources management: A strategic integrated approach. Jordan: Ithraa publishing \& distribution.

Elodealy, N. (1993). Organizational behavior administration (1st ed.). Riyadh.

Elshaweesh, N. (2007). Human resources management: Personnel management. Jordan: Dar Al-Shorok.

Elqariouty, M. (2004). Organizational behavior (4th ed.). Jordan: Dar Al-Shorok.

Heawy, M. (1987). A comparative study of preparing and training university tutor. Journal of the Association of Arab Universities, 22.

Sultan, M. (2004). Human behavior in the organizations. Alexandria: Dar Elgamaa.

Ashour, A. (1983). Public human resources management. Alexandria: Dar Al Marefah.

Abdulwahab, A. (1974). Performance assessment: An analytical study. Cairo: Publications of the Arab organization of administrative sciences.

Darweesh, A. \& Takla, T. (1972). Principles of public administration (2nd ed.). Cairo: Anglo Egyptian Bookshop.

Zedan, S. (2010). Total quality management: Philosophy and approaches II. Jordan: Dar Al Manahej.

Elsharaida, S. (2010). Job satisfaction: Theoretical and practical approaches, (1st ed.). Jordan: Dar Safa.

Aboelnasr, M. (2012). Administration by incentives. Cairo: Arab group of training and publishing.

Report of Najran university's performance indicators: The executive office of Aafaq of the academic year 1435-1436H.

Abdulaziz, S \& Hussien, S. (2005). Quality assurance of higher education institutions accreditation in Egypt: A proposed design, A paper submitted to the 13th annual conference of the Egyptian association of comparative education in collaboration with Beni Suef Faculty of education, Cairo University.

Hussien, S. (2005). Accreditation and quality assurance of education. Cairo: Dar Alnahda 
Alarabia.

Report of Najran university's performance indicators, $1436 \mathrm{H}$.

Storeg, J. (1995). Human resources management, London: Rout Ledge.

Donald, P. (1987). Personnel, human resources management, ( $4^{\text {th }}$ Ed.) Belmont: Calif Kent publishing company.

Geddis, E. (2002). A perspective on tensions between external quality assurance and institutional quality development: A case study. Journal of quality in higher education, 3 (1).

Cheng, Y. (2003). Quality assurance in education, internal, interface and Future. Journal of quality in education, 11(4).

http://mohe.gov.sa/ar/about/Pages/Achievements-and-aspirations.aspx

\section{Copyright Disclaimer}

Copyright for this article is retained by the author(s), with first publication rights granted to the journal.

This is an open-access article distributed under the terms and conditions of the Creative Commons Attribution license (http://creativecommons.org/licenses/by/3.0/). 